\title{
Identification of differentially-expressed genes in response to salt stress in the salt-tolerant Sri Lankan rice variety At354
}

\author{
A.R.F. Zahra ${ }^{1}$, D.M. De Costa ${ }^{{ }^{*}}$ and W.A.J.M. De Costa ${ }^{2}$ \\ ${ }^{1}$ Department of Agricultural Biology, Faculty of Agriculture, University of Peradeniya, Peradeniya. \\ ${ }^{2}$ Department of Crop Science, Faculty of Agriculture, University of Peradeniya, Peradeniya.
}

Revised: 22 January 2013 ; Accepted: 14 February 2013

\begin{abstract}
Rice is highly sensitive to salt stress, an expanding abiotic stress factor that limits rice yield improvement. Development of salt tolerant rice varieties based on molecular breeding methods requires identification of genes responsible for various mechanisms and responses that contribute to salt tolerance. The objective of the present work was to identify genes, which are differentially-expressed in response to salt stress in the salt-tolerant Sri Lankan rice variety, At354. Two cDNA libraries were constructed from mRNA of shoot samples of salt-stressed (100 mM NaCl) At354 at Phase I and Phase II (24 hours and 10 days, respectively after increasing salt stress up to $100 \mathrm{mM}$ ) of salt stress development. A total of 3192 and 960 cDNA clones respectively were screened from Phase I and II libraries. Differential hybridization of the cDNA clones with probes prepared from salt-stressed and unstressed At354 shoot samples enabled identification of up and down-regulated genes in response to salt stress in Phase I and Phase II. The identified, differentially-expressed cDNA clones were re-confirmed by another round of differential hybridization and through Northern hybridization by the RNA dot blot method. Relative reverse transcription polymerase chain reaction (RT-PCR) was performed to compare the expression levels of selected differentially-expressed genes. Sequencing and subsequent homology search in databases identified 14 up-regulated genes and 17 down-regulated genes during Phase I in At354. Similarly, 11 up-regulated genes and 2 down-regulated genes were identified during Phase II. Possible functions of the identified, differentially-expressed genes in conferring salt tolerance in At354 is discussed extensively. These genes may enable exploration of newer avenues for engineering salt tolerance in rice.
\end{abstract}

Keywords: Differential hybridization, gene expression, Oryza sativa, salt stress, salt tolerant genes.

\section{INTRODUCTION}

Rice is one of the most sensitive crops to salt stress
(Munns \& Tester, 2008). Salinity in crop lands has been observed to be spreading because of poor quality of irrigation water and global warming-induced sea level rise. As reclamation of salt affected agricultural lands is difficult and expensive, breeding of salt tolerant rice varieties becomes the only option available to counter increasing salinity. While development of salt tolerant crop varieties is possible through conventional plant breeding strategies (Schubert et al., 2009), molecular based plant breeding strategies offer a more focused, efficient and effective approach to develop salt tolerant varieties (Ashraf \& Akram, 2009). Molecular based breeding strategies could be especially useful in rice, where the entire genome has been sequenced. Such strategies require identification of physiological mechanisms that confer salt tolerance and the putative genes that are responsible for such mechanisms of tolerance (Munns \& Tester, 2008; Rajendran et al., 2009).

The two-phase growth response of plants to salinity as developed by Munns (2002) forms the physiological basis of a plants' response to salt stress. The two-phase model postulates that plants respond in two sequential phases to increasing salinity. The first phase of salt stress development (Phase I) occurs immediately upon exposure to a salt ion concentration above a threshold ECe of $4 \mathrm{dS} \mathrm{m}^{-1}\left(1.9 \mathrm{dS} \mathrm{m}^{-1}\right.$ for rice), which is equivalent to $40 \mathrm{mM} \mathrm{NaCl}$ (19 mM NaCl for rice), for most plant species (Munns \& Tester, 2008). During Phase I, excess salt ions in the external soil solution decreases its osmotic potential thereby decreasing the ability of plant roots to absorb water. In this phase of 'osmotic stress', plants show the typical responses to drought stress. With increasing salt concentrations in the external soil solution and/or with increasing duration spent in a saline soil, salt ion concentrations in the meristematic tissues increase

*Corresponding author (devikacos@yahoo.com) 
beyond the capacity of cells to compartmentalize the excess into the vacuole. As a result, the plant enters the second phase of salt stress development (Phase II) in which salt concentration increases in the cytoplasm, where all the important physiological processes take place, to toxic levels resulting in gradual injury and death of tissue.

The two-phase model forms the basis for identification of mechanisms that are responsible for salt tolerance. Accordingly, three major mechanisms can be identified. Salt tolerance during Phase I can be achieved primarily by tolerance to osmotic stress (Mechanism No. 1), which involves maintenance of shoot and root growth even under salt stress. Hence, a tolerant genotype may show a lower growth reduction than a sensitive genotype. Tolerance during Phase II may be achieved by either salt exclusion from photosynthesizing leaves (Mechanism No. 2) and/or by increasing the tissue tolerance to excess salt (Mechanism No. 3). As sodium chloride is the most abundant and soluble salt that is released from weathering of rocks (Szabolcs, 1989), saltstressed plants have to develop tolerance mechanisms primarily against $\mathrm{Na}^{+}$and $\mathrm{Cl}^{-}$ions. Out of these two ions, $\mathrm{Na}^{+}$toxicity often develops earlier than $\mathrm{Cl}^{-}$toxicity (Munns \& Tester, 2008). Consequently, the majority of research on tolerance to salt ion toxicity has focused on mechanisms of exclusion of and tissue tolerance to $\mathrm{Na}^{+}$.

At354 is the popular salt tolerant improved rice variety, developed through incorporation of salt tolerant genes from 'Pokkali', a traditional salt tolerant rice variety in Sri Lanka. However, genes that are responsible for salt tolerance in At354 have not been identified.

Determination of the gene expression patterns under salt stress in identified salt tolerant varieties is one approach to identify putative genes of salt tolerance (Kawasaki et al., 2001). Altering the expression of identified putative genes of salt tolerance has been shown to improve tolerance (Zhang et al., 1999). Thus, the objective of the present work was to identify genes, which are differentially-expressed in response to salt stress in the salt-tolerant Sri Lankan rice variety At354.

\section{METHODS AND MATERIALS}

\section{Plant culture, salt treatments and sample collection}

Rice variety At354 was grown hydroponically in a rainsheltered planthouse at the Agricultural Biotechnology Centre, University of Peradeniya, Peradeniya. A specific nutrient solution for hydroponic culture of rice (Yoshida et al., 1972) was used to grow the plants. Composition of the full-strength nutrient solution was: (in $\left.\mathrm{gL}^{-1}\right) \mathrm{NH}_{4} \mathrm{NO}_{3}$, 91.4; $\mathrm{NaH}_{2} \mathrm{PO}_{2} .2 \mathrm{H}_{2} \mathrm{O}, 40.3 ; \mathrm{K}_{2} \mathrm{SO}_{4} 71.4 ; \mathrm{MgSO}_{4} .7 \mathrm{H}_{2} \mathrm{O}$, $324 ; \mathrm{CaCl}_{2}$. 88.6; $\mathrm{MnCl}_{2} \cdot 4 \mathrm{H}_{2} \mathrm{O}, 1.5 ;\left(\mathrm{NH}_{4}\right)_{6} \cdot \mathrm{Mo}_{7} \mathrm{O}_{24} \cdot 4 \mathrm{H}_{2} \mathrm{O}$, $0.074 ; \mathrm{H}_{3} \mathrm{BO}_{3} \mathrm{ZnSO}_{4} .7 \mathrm{H}_{2} \mathrm{O}, 0.035 ; \mathrm{CuSO}_{4} .5 \mathrm{H}_{2} \mathrm{O}, 0.031$; $\mathrm{FeCl}_{3} \cdot 6 \mathrm{H}_{2} \mathrm{O}$, 7.7; Citric acid, 11.9. Micronutrient salts were dissolved separately and combined with $50 \mathrm{~mL}$ conc. $\mathrm{H}_{2} \mathrm{SO}_{4}$ and the volume was adjusted to $1 \mathrm{~L}$ by distilled water (final $\mathrm{pH}=5.00$ ). The seeds were germinated on moist filter papers and transferred to $1 / 4$ strength nutrient solutions in $3 \mathrm{~L}$ pots $1 \mathrm{wk}$ after germination. Strength of the nutrient solution was increased in $25 \%$ steps up to full strength at $2 \mathrm{~d}$ intervals. Salt treatments started a week after giving the full strength nutrient solution. The salt-stress treatment started at $25 \mathrm{mM} \mathrm{NaCl}$ and was increased up to a final concentration of $100 \mathrm{mM}$ in $25 \mathrm{mM}$ steps at $2 \mathrm{~d}$ intervals. The unstressed control treatment was maintained at $1 \mathrm{mM} \mathrm{NaCl}$.

Plants were harvested for Phases I and II at $24 \mathrm{~h}$ and $10 \mathrm{~d}$, respectively after increasing the salinity up to 100 $\mathrm{mM} \mathrm{NaCl}$ as determined by a separate experiment (De Costa et al., 2012). Immediately after harvesting, the shoots and roots were separated, snap frozen and ground in liquid nitrogen to be used for extraction of RNA.

\section{Extraction of total RNA and mRNA from rice shoots and construction of cDNA libraries}

RNA was extracted from shoot tissues of both Phase I and II by modifying the method of Suzuki et al. (2001) with Trizol method (Invitrogen, USA). Quality and integrity of the extracted RNA samples were determined spectrophotometrically and by running in a denaturing agarose gel. Samples of mRNA were extracted from the total RNA samples isolated from the shoot tissues at Phase I and II by the paramagnetic particle technique using Dynal beads (Dynal Biotech ASA, Norway) according to the manufacturer's instructions. Two cDNA libraries were prepared, one each from mRNA of salt treated shoot tissues harvested at Phase I (OsPHI) and Phase II (OsPHII). The cDNA library was constructed using CloneMiner ${ }^{\mathrm{TM}}$ cDNA Library Construction kit (Catalogue No. 18249-029, Invitrogen, USA) based on Gateway $^{\mathrm{R}}$ Technology according to the manufacturer's instructions. Individual cDNA clones were designated with code numbers and stored in LB medium supplemented with kanamycin $(50 \mu \mathrm{g} / \mathrm{mL})$.

Detection of salt-responsive clones in OsPHI and OsPHII libraries by differential-hybridization

A total of 3192 cDNA clones of OsPHI library and 960 cDNA clones of OsPHII were arrayed separately onto sterilized nylon membranes (Hybond $\mathrm{N}^{+}$, Amersham 
Pharmacia, USA). Membranes with well grown colonies were lysed, neutralized, washed and fixed to be used for hybridization. Probes for hybridization were prepared using total RNA extracted from salt treated rice shoot samples (treated probe) and shoot tissues of non-salt treated plants (control probe) collected at Phase I and II. Probes were labelled with digoxygenin according to the instructions of Roche, Germany (Cat. No. 11093657910). The cDNA colonies of OsPHI and OsPHII libraries fixed on membranes were subjected to differential hybridization separately, according to the method described by the manufacturer (Cat. No. 11093657910 , Roche, Germany).

Briefly, and with reference to membranes containing colonies of OsPHI library, the initial hybridization was done with the control probe. The colonies with positive signals were detected on X-ray films by chemeluminescence and according to the instructions of Roche, Germany (Cat. No.11093657910). After the positive clones were recorded by their designation codes, the control probe on the membrane was stripped off and the same membrane was subjected to hybridization with the treated probes. Once again, the positive clones for treated probes (i.e. clones giving higher signal intensity) were selected by their designation codes upon detection by chemiluminescence. Based on the signal intensity given on X-ray film, cDNA clones which were having up-regulated and down-regulated genes under salt stress were detected as described by Xiong et al. (2001). Briefly, a cDNA clone, which is having an up-regulated gene in response to salt stress would show higher signal intensity when hybridized with the treated probe than the signal intensity given by the control probe. In contrast, cDNA clones, which are having down-regulated genes in response to salt stress would show lower signal intensity to the treated probe relative to the control probe.

The same differential hybridization procedure was employed for the membrane blots having cDNA clones of OsPHII library to detect the clones having up - and down-regulated genes at Phase II of salt stress. The selected cDNA clones with up - and down-regulated genes at Phases I and II were reconfirmed with another round of differential hybridization, conducted only for those selected clones.

\section{Identification of candidate genes in CDNA clones with up- and down-regulated genes}

For identification of putative genes, which are upor down-regulated due to salt stress at Phases I and II, sequencing and subsequent homology search were conducted. To this end, plasmid extraction was done by alkaline SDS method (Sambrook et al., 1989) from selected cDNA clones by differential hybridization. The plasmid pDONR ${ }^{\mathrm{TM}} 222$ harboured by the cDNA clones contain cDNA fragments of different genes expressed as up- or down-regulated genes under salt stress. Plasmid extraction was done for all the selected cDNA clones of both OsPHI and OsPHII libraries. The cDNA fragments harboured in extracted plasmids were amplified by M13 universal primers (M13F- 5'GTAAAACGACGGCCAG3' and M13R5'CAGGAAACAGCTATGAC3') for 30 repeated cycles having the following PCR reaction conditions: denaturing step at $94{ }^{\circ} \mathrm{C}$ for $30 \mathrm{~s}$; annealing step at $50{ }^{\circ} \mathrm{C}$ for $2 \mathrm{~min}$ and extension step at $72{ }^{\circ} \mathrm{C}$ for $30 \mathrm{~s}$. The PCR products obtained were subjected to DNA sequencing at GeneTech, Sri Lanka. DNA sequence information obtained for each PCR product was subjected to homology search using available DNA and protein databases (i.e. BLASTN and BLASTP of NCBI, respectively).

\section{Confirmation of differential expression of identified candidate genes of OsPHI and OsPHII libraries by dot blot analysis}

\section{RNA dot blot method}

RNA dot blot method was conducted as described by Kafatos et al. (1979) and Rapley (2000). Briefly, a piece of Hybond $\mathrm{N}^{+}$membrane was soaked in DEPC treated water for $1 \mathrm{~min}$. The membrane was transferred to a solution of $20 \mathrm{x} \mathrm{SSC}$, soaked for $2 \mathrm{~min}$ and allowed to air dry for $20 \mathrm{~min}$. Equal concentrations of total RNA samples extracted separately from salt-treated and control plants were spotted on to the dried membrane, side by side. The membranes were air-dried for $30 \mathrm{~min}$, covered with two Whatman filter papers and oven-baked for $2 \mathrm{~h}$ at $80{ }^{\circ} \mathrm{C}$. The membranes were stored at $-20{ }^{\circ} \mathrm{C}$, under dark conditions until they were used for Northern hybridization.

Probes needed for RNA dot blot hybridization were prepared as follows: several cDNA clones carrying the identified up- and down-regulated genes at both phases were subjected to PCR amplification using standard M13 primers. The amplified PCR products of each selected cDNA clone were labelled with Dig DNA labelling and detection kit as instructed by the manufacturer (Roche, Germany, Cat. No.11093657910). As a reference gene for comparison of gene expression, $\alpha$-tubulin gene (i.e. a housekeeping gene) was amplified using total RNA extracted from shoot tissues of salt-treated and non salt-treated plants using the primer pair 5' TACCGTGCCCTTACTGTTCC3' and 5'CGGTGGAATGTCACAGACAC3'. The PCR 
programme consisted of 30 cycles, each having a denaturing step of $94^{\circ} \mathrm{C}$ for $30 \mathrm{~s}$, an annealing step of $50^{\circ} \mathrm{C}$ for $30 \mathrm{~s}$ and an extension step of $72^{\circ} \mathrm{C}$ for $30 \mathrm{~s}$. Independent hybridization procedures were conducted for each probe prepared from each selected cDNA clone (up- or downregulated). Positively-hybridized clones were detected by the colorimetric method using Dig detection kit (Roche, Germany, Cat. No.11093657910). Intensity of signals produced on RNA blots of salt stressed and control plants was quantified by scanning the Northern blots and analyzing the signal intensity using the UNSCAN-IT software, which converts scanned images into data (Silk Scientific Inc, USA). Relative signal intensity values were calculated by comparing the intensities of salt treated samples with control (i.e. non salt treated) samples according to the method described by Wilen et al. (1993).

Comparative expression analysis of some selected genes of OsPHI library during Phase I and Phase II by relative RT-PCR

Relative RT-PCR, as suggested by Gause and Adamovicz (1995) was performed to compare the expression levels of selected genes of salt tolerance of OsPHI library during Phases I and II of salt stress as follows:

Total RNA was extracted from shoots of salt stressed and control plants harvested at the two phases, and genomic DNA was eliminated by treating with DNase 1 (Promega, USA). DNase I treated RNA samples were subjected to cDNA synthesis by SuperScript ${ }^{\mathrm{TM}}$ First-Strand synthesis system (Invitrogen, USA) as recommended by the manufacturer. Synthesized cDNA from total RNA samples extracted from salt stressed and unstressed control plants harvested at Phases I and II were quantified using Biospec-Nano Spectrophotometer (Shimadzu, Japan) and samples having the same concentration were taken to perform relative RT-PCR.

RT-PCR reaction was performed with gene specific oligonucleotide primers designed for three upregulated genes identified from Phase I of salt treated plants. Designation codes of cDNA clones carrying those up-regulated genes of Phase I library (OsPHI) were OsPHI-30, OsPHI-147 and OsPHI-928 and the cDNA fragments carried by those clones were also designated by the same codes. Based on the DNA sequence information available for those three cDNA clones, the following sequence specific primers were designed for RT-PCR amplifications:OSPH1-30F -5'GGCTCCTTCCTCCACTACC-3' / OSPH1-30R - 5'CCAAAGCTTCACCCTCCAC-3', OSPH1-147F-5'-
GGAGCTTTGTGTTGTTGTC-3'OSPH1-147R-5'CTTAACTGTAATATCCTGACG-3', OSPH1-147F- 5'GTTGGATTATATGTTCGTTC-3'\% OSPH1-147R- 5'CATTTGTAGAGTTGTACAAC-3'.

RT-PCR was performed with cDNA of salt stressed and unstressed plants obtained at Phases I and II, targeting the up-regulated genes and the reference gene ( $\alpha$-tubulin). For amplification of the tubulin gene, specific primers were used (TubF-5' - TACCGTGCCCTTACTGTTCC -3'/ TubR-5' - CGGTGGAATGTCACAGACAC -3'). All PCR amplifications were performed using thermocycler (Techne, USA), having 35 cycles at $94{ }^{\circ} \mathrm{C}$ for $30 \mathrm{~s}, 55^{\circ} \mathrm{C}$ for $1 \mathrm{~min}$ and $72^{\circ} \mathrm{C}$ for $1 \mathrm{~min}$.

PCR products were separated on $1.2 \%$ agarose gels and the gel was stained with ethidium bromide to visualize the amplified PCR products. Thereafter, photographic images were obtained with a gel documentation system. Densitometric analyses were performed with the Gel UN-SCAN-IT software (Silk Scientific, USA) as described by Dean et al. (2002). The relative intensity was determined based on the intensities of the reference gene and the genes of interest. The average pixel values were calculated for the reference gene and each of the genes of interest by Gel UN-SCAN-IT software (Silk Scientific, USA). To identify the relative expression, the ratio of the gene of interest band intensity to reference/ control gene band intensity was calculated in salt treated and non salt treated plants.

\section{RESULTS}

Identification of salt stress responsive genes, which are expressed during Phase I of rice variety At354

Based on differential hybridization signals, 48 and 66 different cDNA clones were identified as clones carrying up- and down-regulated genes, respectively at Phase I of salt stress. These up- and down-regulated clones were reconfirmed for the up- or down-regulated gene expression by another round of differential hybridization on separately prepared nylon membranes. The second round of differential hybridization confirmed $22 \mathrm{cDNA}$ clones as up-regulated and 30 cDNA clones as downregulated at Phase I (Figures 1.a \& 1.b).

Sequencing the PCR products of OsPHI cDNA library and homology search

Among the 52 PCR products sent for DNA sequencing, successful results were obtained for $31 \mathrm{cDNA}$ clones in which 14 were for up-regulated clones and 17 for 
(A)
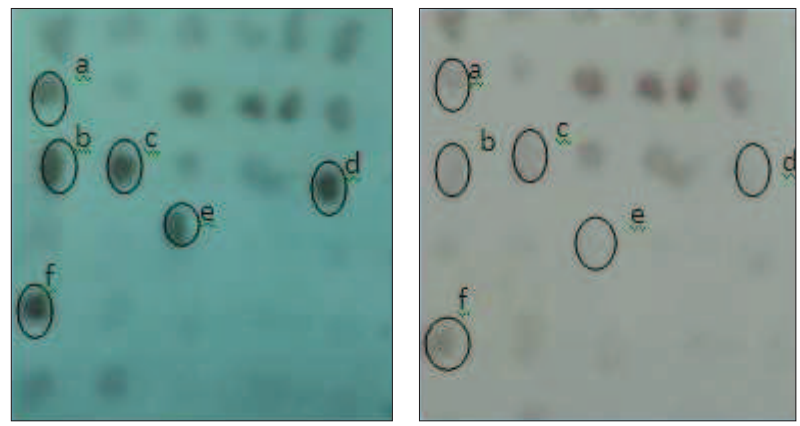

Figure 1.a: Identified up-regulated clones at Phase I of salt stress development. Signals developed by salt-treated cDNA probe (A) and control cDNA probe (B) when the selected cDNA clones were subjected to differential hybridization. Six differentially hybridized clones corresponding to clones (a) 30, (b) 32, (c) 147, (d) 194, (e) 928 and (f) 1271 are indicated by circles.
(A)

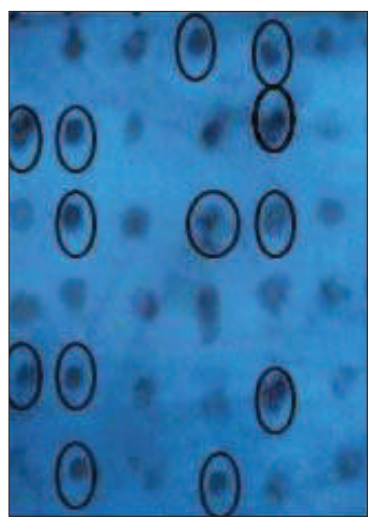

(B)

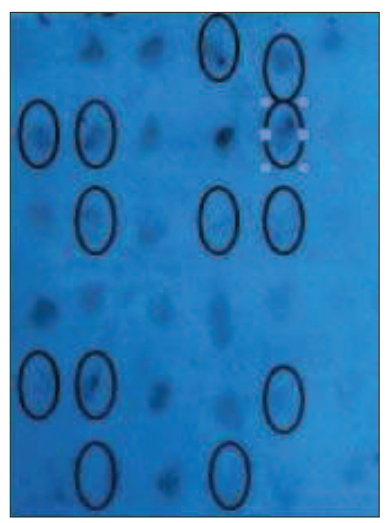

Figure 2.a: Identified up-regulated clones at Phase II of salt stress development. Signals developed by salt treated cDNA probe (A) and control cDNA probe (B) when the selected cDNA clones were subjected to differential hybridization. Thirteen up-regulated clones are indicated by circles.

down-regulated clones. Homology search was done for the DNA sequences of the 31 cDNA fragments and Tables 1 and 2 summarize the putative genes and their possible functions of the $31 \mathrm{cDNA}$ clones, which were differentially-expressed in At354 in response to salt stress during Phase I.
(A)

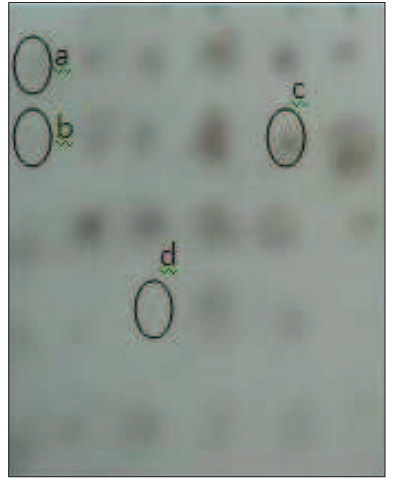

(B)

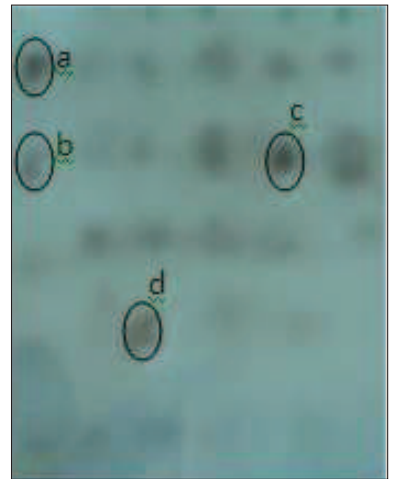

Figure 1.b: Identified down -regulated clones at Phase I of salt stress development. Signals developed by salt treated cDNA probe (A) and control cDNA probe (B) when the selected cDNA clones were subjected to differential hybridization. Four differentially hybridized clones corresponding to clones (a) 230, (b) 2792, (c) 2805 and (d) 2855 are indicated by circles.

(A)

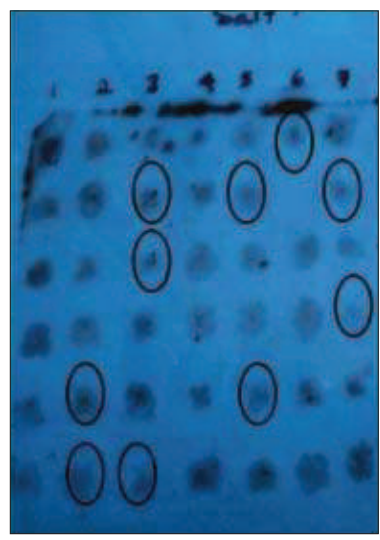

(B)

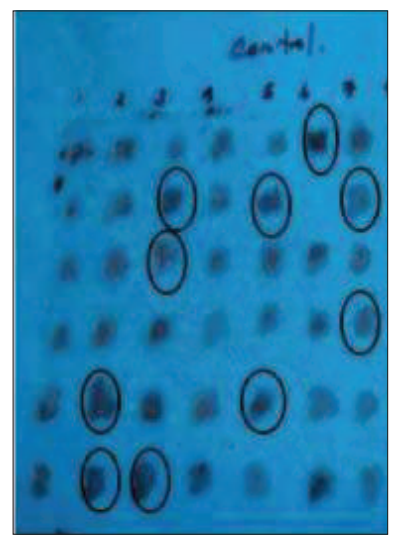

Figure 2.b: Identified down-regulated clones at Phase II of salt stress development. Signals developed by salt treated cDNA probe (A) and control cDNA probe (B) when the selected cDNA clones were subjected to differential hybridization. Ten down-regulated clones are indicated by circles.

Identification of salt stress responsive genes, which are expressed during Phase II of rice variety At354

Differential screening of 960 clones from salt stressinduced Phase II cDNA library identified 48 cDNA 
Table 1: Putative genes and probable proteins produced by the up-regulated cDNA clones of the salt tolerant Sri Lankan rice variety At354 during Phase I of salt stress development

\begin{tabular}{|c|c|c|c|}
\hline Clone No. & Homology information & Identity & Probable function under salt stress \\
\hline OsPHI-30 & $\begin{array}{l}\text { Putatively expressed salt tolerant gene of rice } \\
\text { identified previously from Oryza sativa Japonica } \\
\text { (variety Nipponbare) }\end{array}$ & D 75 & $\begin{array}{l}\text { No information on the physiological function is available. } \\
\text { May be a novel unreported gene }\end{array}$ \\
\hline OsPHI-32 & $\begin{array}{l}\text { Homologous to eukaryotic translation initiation } \\
\text { factor eIF5A }\end{array}$ & D 96 & $\begin{array}{l}\text { Protection of older leaves from salt ion toxicity; Exclusion } \\
\text { of } \mathrm{Na}^{+} \text {from younger leaves }\end{array}$ \\
\hline OsPHI-33 & $\begin{array}{l}\text { Homologous to cytochrome oxidase I of } \\
\text { mitochondria }\end{array}$ & D 87 & Activation of mitochondria to adapt to osmotic stress \\
\hline OsPHI-147 & $\begin{array}{l}\text { Homologous to a gene of Oryza sativa which } \\
\text { produces a putative serine decarboxylase }\end{array}$ & D 97 & $\begin{array}{l}\text { Increased biosynthesis of glycinebetaine, an } \\
\text { osmoprotectant }\end{array}$ \\
\hline OsPHI-194 & $\begin{array}{l}\text { Homologous to a gene similar to LSTK-1- } \\
\text { like kinase of Oryza sativa Japonica (variety } \\
\text { Nipponbare) }\end{array}$ & D 99 & Osmotic stress/drought tolerance \\
\hline OsPHI-240 & $\begin{array}{l}\text { Homologous to WD40-like domain containing } \\
\text { protein }\end{array}$ & D 91 & Function via regulatory pathway to tolerate osmotic stress \\
\hline OsPHI-928 & $\begin{array}{l}\text { Homologous to a putative gene of Oryza sativa that } \\
\text { produces AP domain DRE binding factor }\end{array}$ & D 100 & Osmotic stress/drought tolerance \\
\hline OsPHI-941 & Homology to Zinc finger protein 1-like isoform & D 81 & $\begin{array}{l}\text { Enhance the activities of reactive oxygen species- } \\
\text { scavenging enzymes under stress conditions and increased } \\
\text { tolerance of plants to oxidative stress }\end{array}$ \\
\hline OsPHI-1271 & $\begin{array}{l}\text { Homologous to a putative gene which produces a } \\
\text { chromosomal replication initiator protein }\end{array}$ & D 96 & $\begin{array}{l}\text { No information is available on physiological function. } \\
\text { May be a novel unreported gene }\end{array}$ \\
\hline OsPHI-2277 & Homology to EST of water-stressed durum wheat & D 100 & Osmotic stress/drought tolerance \\
\hline OsPHI-2465 & Homology to EST of water-stressed durum wheat & D 95 & Osmotic stress/drought tolerance \\
\hline OsPHI-2468 & $\begin{array}{l}\text { Homology to a hypothetical protein of Oryza } \\
\text { sativa }\end{array}$ & D 89 & $\begin{array}{l}\text { No information is available on physiological function. } \\
\text { May be a novel unreported gene }\end{array}$ \\
\hline OsPHI- 2470 & $\begin{array}{l}\text { Similar to receptor-like kinase protein of Oryza } \\
\text { sativa }\end{array}$ & D 88 & $\begin{array}{l}\text { Salt and drought stress tolerance in rice, through the } \\
\text { activation of antioxidant systems }\end{array}$ \\
\hline OsPHI-2487 & Homology to SET domain protein & D 86 & Osmotic stress/drought tolerance \\
\hline
\end{tabular}

D- Percent identity in nucleotide sequence

clones as salt-responsive, out of which 34 were upregulated and 14 were down-regulated. Figures 2.a and 2.b present 13 of the up-regulated and 10 of the downregulated genes indicated above. These selected clones were reconfirmed as up- and down-regulated clones by subjecting to another round of differential hybridization.

\section{Sequencing of the PCR products of OsPHII cDNA library and homology search}

Among the 48 PCR products sent for DNA sequencing successful results were obtained only for $13 \mathrm{cDNA}$ clones consisting of 11 up- and 2 down-regulated clones. Tables
3 and 4 summarize the putative genes of 13 cDNA clones by homology search and their possible functions, which were differentially-expressed in At354 in response to salt stress during Phase II of salt stress.

\section{Confirmation of differential expression of identified candidate genes of OsPHI and OsPHII libraries by dot blot analysis}

When northern hybridization was done by the dot blot method using $\alpha$-tubulin and gene specific probes, visible signals were obtained in the dot blots. As shown in Tables 5 and 6 , the average pixel values of the signals of the 
Table 2: $\quad$ Putative genes and probable proteins produced by the down-regulated cDNA clones of the salt tolerant Sri Lankan rice variety At354 during Phase I of salt stress development

\begin{tabular}{|c|c|c|c|}
\hline Clone No. & Homology information & Identity & Probable function under salt stress \\
\hline OsPHI-42 & $\begin{array}{l}\text { Aldo keto reductase family protein of Oryza } \\
\text { sativa }\end{array}$ & D 84 & Function via metabolic pathway to tolerate salt stress \\
\hline OsPHI-54 & $\begin{array}{l}\text { Homologous to a gene similar to enolase } \\
\text { (2-phosphoglycerate dehydratase) }\end{array}$ & D 100 & $\begin{array}{l}\text { This enzyme may play a role in decreasing energy metabolism } \\
\text { rates to conserve energy and limit further generation of } \\
\text { reactive oxygen species (ROS) }\end{array}$ \\
\hline OsPHI-154 & $\begin{array}{l}\text { Homologous to a hypothetical protein of } \\
\text { Arabiodopsis lyrata sub sp. }\end{array}$ & D 92 & No information is available on physiological function \\
\hline OsPHI-172 & $\begin{array}{l}\text { Homology to a hypothetical protein of } \\
\text { Nipponbare cultivar of Oryza sativa }\end{array}$ & D 86 & $\begin{array}{l}\text { No information is available on physiological function. May } \\
\text { be a novel unreported gene }\end{array}$ \\
\hline OsPHI-181 & $\begin{array}{l}\text { Homologous to a gene similar to beta-amyrin } \\
\text { synthase of Oryza sativa }\end{array}$ & D 94 & No information is available on physiological function \\
\hline OsPHI-183 & Similar to $30 \mathrm{~S}$ ribosomal protein $\mathrm{S} 18$ & D 87 & $\begin{array}{l}\text { Regulation of gene expression by suppressing bulk protein } \\
\text { synthesis }\end{array}$ \\
\hline OsPHI -230 & Homologous to amine oxidases & D 89 & $\begin{array}{l}\text { Reduced degradation of polyamines and ensures tolerance of } \\
\text { osmotic stress and ion toxicity; Reduced production of } \mathrm{H}_{2} \mathrm{O}_{2}\end{array}$ \\
\hline OsPHI-719 & $\begin{array}{l}\text { Similar to photosystem II P680 chlorophyll A } \\
\text { apoprotein (CP-47 protein) }\end{array}$ & D 90 & $\begin{array}{l}\text { May prevent photoinhibitory damage due to the formation of } \\
\text { reactive oxygen species (ROS) }\end{array}$ \\
\hline OsPHI-841 & $\begin{array}{l}\text { Homologous to a hypothetical protein of } \\
\text { Arabiodopsis lyrata sub sp. }\end{array}$ & D 81 & No information is available on physiological function \\
\hline OsPHI-864 & $\begin{array}{l}\text { Homology to a hypothetical protein of } \\
\text { Nipponbare cultivar of Oryza sativa }\end{array}$ & D 86 & $\begin{array}{l}\text { No information is available on physiological function. May } \\
\text { be a novel unreported gene }\end{array}$ \\
\hline OsPHI-937 & $\begin{array}{l}\text { Homologous to EST found in male and female } \\
\text { panicle of Pistacia vera }\end{array}$ & D 83 & $\begin{array}{l}\text { No information is available on physiological function. May } \\
\text { be a novel unreported gene }\end{array}$ \\
\hline OsPHI -939 & Similar to $30 \mathrm{~S}$ Ribosomal protein S18 & D 87 & $\begin{array}{l}\text { Regulation of gene expression by suppressing bulk protein } \\
\text { synthesis }\end{array}$ \\
\hline OsPHI-1142 & $\begin{array}{l}\text { Homology to a hypothetical protein of } \\
\text { Nipponbare cultivar of Oryza sativa }\end{array}$ & D 91 & $\begin{array}{l}\text { No information is available on physiological function. May } \\
\text { be a novel unreported gene }\end{array}$ \\
\hline OsPHI-2792 & Homologous to amine oxidases & D 70 & $\begin{array}{l}\text { Reduced degradation of Polyamines and ensures tolerance of } \\
\text { osmotic stress and ion toxicity; Reduced production of } \mathrm{H}_{2} \mathrm{O}_{2}\end{array}$ \\
\hline OsPHI-2805 & $\begin{array}{l}\text { Homology to protein product of rap-GTPase- } \\
\text { activating protein }\end{array}$ & P 100 & $\begin{array}{l}\text { Stomatal closure through down-regulation of cyclic } \\
\text { neucleotide pathway; Cytoplasmic ion homeostasis }\end{array}$ \\
\hline OsPHI-2806 & $\begin{array}{l}\text { Homology to a hypothetical protein of } \\
\text { Nipponbare cultivar of Oryza sativa }\end{array}$ & D 90 & $\begin{array}{l}\text { No information is available on physiological function. May } \\
\text { be a novel unreported gene }\end{array}$ \\
\hline OsPHI-2855 & $\begin{array}{l}\text { Homology to agmatine deiminase protein } \\
\text { product }\end{array}$ & P 100 & $\begin{array}{l}\text { Reduced production of putrescine to increase osmotic } \\
\text { tolerance }\end{array}$ \\
\hline
\end{tabular}

D- Percent identity in nucleotide sequence; P- percent identity in amino-acid sequence

two samples of $\alpha$-tubulin (i.e. control and salt treated), which were hybridized with gene specific probes were more or less similar to each other. In contrast, the average pixel values of the salt treated sample were higher in comparison to that of salt non-treated samples when the samples were hybridized with probes OSPHI-30, OSPHI-147, OSPHI-194 and OSPHI-928 of OSPHI cDNA library and OSPHII-1, OSPHII-51, OSPHII-311, 
Table 3: Putative genes and probable proteins produced by the up-regulated cDNA clones of the salt-tolerant Sri Lankan rice variety At 354 during Phase II of salt-stress development

\begin{tabular}{|c|c|c|c|}
\hline Clone No. & Homology information & Identity & Probable function under salt stress \\
\hline OsPHII-1 & Similar to dicarboxylate transporters & D 92 & $\begin{array}{l}\text { Transports malate to vacuole and regulates stomatal } \\
\text { opening }\end{array}$ \\
\hline OsPHII-11 & $\begin{array}{l}\text { Dehydration responsive element binding protein of } \\
\text { Zea mays }\end{array}$ & D 92 & Transcriptional regulation of stress gene expression \\
\hline OsPHII-51 & $\begin{array}{l}\text { Similar to heat shock protein (HSP81-1) / (HSP83) } \\
\text { of Zea mays }\end{array}$ & D 95 & $\begin{array}{l}\text { Hsps/chaperones play a crucial role in protecting plants } \\
\text { against stress and in the re-establishment of cellular } \\
\text { homeostasis }\end{array}$ \\
\hline OsPHII-77 & $\begin{array}{l}\text { Homology to a hypothetical protein of Oryza sativa } \\
\text { (variety Nipponbare) }\end{array}$ & D 92 & $\begin{array}{l}\text { No information is available on physiological function. May } \\
\text { be novel unreported genes }\end{array}$ \\
\hline OsPHII-133 & $\begin{array}{l}\text { Similar to heat shock protein (HSP81-1) / (HSP83) } \\
\text { of Zea mays }\end{array}$ & D 95 & $\begin{array}{l}\text { Hsps/chaperones play a crucial role in protecting plants } \\
\text { against stress and in the re-establishment of cellular } \\
\text { homeostasis }\end{array}$ \\
\hline OsPHII-151 & $\begin{array}{l}\text { Similar to peroxidase precursor of Oryza sativa } \\
\text { Japonica (variety Nipponbare) }\end{array}$ & D 95 & Detoxification of free oxygen radicals \\
\hline OsPHII-311 & $\begin{array}{l}\text { Similar to MADs box protein of Oryza sativa } \\
\text { (variety Nipponbare) }\end{array}$ & D 88 & Transcriptional regulation of stress gene expression \\
\hline OsPHII-331 & Ubiquitin-protein ligase of Arabidopsis thaliana & D 92 & Protein turnover \\
\hline OsPHII-370 & $\begin{array}{l}\text { Homology to a hypothetical protein of Oryza sativa } \\
\text { (variety Nipponbare) }\end{array}$ & D 96 & $\begin{array}{l}\text { No information is available on physiological function. May } \\
\text { be novel unreported genes }\end{array}$ \\
\hline OsPHII-373 & $\begin{array}{l}\text { EF-Hand type domain containing protein of Oryza } \\
\text { sativa (variety Nipponbare) }\end{array}$ & D 90 & Stress signal transduction and gene expression \\
\hline OsPHII-590 & Harpin inducing protein & D 87 & $\begin{array}{l}\text { Activation of ethylene-response factor } 5 \text { (SlERF5) to } \\
\text { tolerate salt stress }\end{array}$ \\
\hline
\end{tabular}

D- Percent identity in nucleotide sequence

Table 4: Putative genes and probable proteins produced by the down-regulated cDNA clones of the salt-tolerant Sri Lankan rice variety At354 during Phase II of salt-stress development

\begin{tabular}{llcl}
\hline Clone No. & Homology information & Identity & Probable function under salt stress \\
\hline OsPHII-159 & $\begin{array}{l}\text { Homology to a hypothetical protein of } \\
\text { Oryza sativa }\end{array}$ & D 88 & $\begin{array}{l}\text { No information is available on physiological function. May be } \\
\text { a novel unreported gene }\end{array}$ \\
OsPHII-333 & $\begin{array}{l}\text { Similar to KN motif and ankyrin repeat } \\
\text { domains protein of Ciona intestinalis }\end{array}$ & D 88 & $\begin{array}{l}\text { May function as negative regulator of gluthathione S-transferase } \\
\text { and thereby contributes to antioxidation function }\end{array}$ \\
\hline
\end{tabular}

D- Percent identity in nucleotide sequence 
Table 5: RNA dot blot results and average pixel values quantified with a computer aided software for differentially-expressed genes of OsPHI cDNA library

\begin{tabular}{|c|c|c|c|c|c|}
\hline \multirow{2}{*}{ Probe } & \multicolumn{2}{|c|}{ Sample description } & \multicolumn{2}{|c|}{ Average pixel value } & \multirow{2}{*}{$\begin{array}{c}\text { Relative expression of } \\
\text { treatment compared t } \\
\text { control }\end{array}$} \\
\hline & Control & Treatment & Control & Treatment & \\
\hline Tubulin & & $\rightarrow \infty$ & 156.41 & 156.91 & Similar \\
\hline OSPHI 30 & (3) & 9 & 149.78 & 151.17 & High \\
\hline OSPHI 147 & & & 183.37 & 206.38 & High \\
\hline OSPHI 194 & & & 179.58 & 188.31 & High \\
\hline OSPHI 928 & & & 150.06 & 171.17 & High \\
\hline OSPHI 939 & & & 227.55 & 212.8 & Low \\
\hline OSPHI 2855 & & & 233.43 & 225.18 & Low \\
\hline OSPHI 172 & & & 173.88 & 153.27 & Low \\
\hline
\end{tabular}


Table 6: RNA dot blot results and average pixel values quantified with a computer aided software for differentially-expressed genes of OsPHII cDNA library

\begin{tabular}{|c|c|c|c|c|c|}
\hline \multirow{2}{*}{ Probe } & \multicolumn{2}{|c|}{ Sample description } & \multicolumn{2}{|c|}{ Average pixel value } & \multirow{2}{*}{$\begin{array}{l}\text { Relative expression of treatment } \\
\text { compared to control }\end{array}$} \\
\hline & Control & Treatment & Control & Treatment & \\
\hline Tubulin & & & 165.32 & 165.74 & Similar \\
\hline OSPHII 1 & & & 183.43 & 210.52 & High \\
\hline OSPHII 51 & 0 & & 165.39 & 217.53 & High \\
\hline OSPHII 311 & & & 199.32 & 229.28 & High \\
\hline OSPHII 370 & & & 111.95 & 147.76 & High \\
\hline OSPHII 590 & & & 163.16 & 167.74 & High \\
\hline OSPHII 333 & & $\varphi$ & 167.88 & 144.91 & Low \\
\hline
\end{tabular}

OSPHII-370, OSPHII-590 of OSPHII cDNA library. All these were up-regulated cDNA clones. In contrast, the average pixel values of the salt treated sample were lower in comparison to non-treated samples when the samples were hybridized with probes OSPHI-939, OSPHI-2855, OSPHI-172 of OSPHI cDNA library and OSPHII-333 of OSPHII cDNA library. All these were down-regulated cDNA clones.
Comparative expression analysis of some selected genes of OsPHI library at Phase I and Phase II by relative RT-PCR

The relative RT-PCR gels of selected genes of salt tolerance for Phase I and II are shown in Figure 3. As shown in Table 7, during Phase I, relative expression of OsPHI-30, OsPHI-147, OsPHI-928 were higher in 
(A)

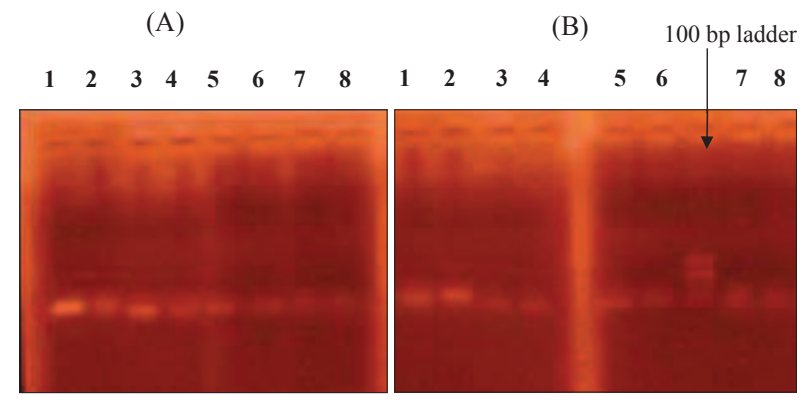

Figure 3: (A) Relative RT-PCR gel of Phase I plant samples; (B) Relative RT-PCR gel of Phase II plant samples. 1 - Tubulin gene of control plant; 2 - Tubulin gene of salt-treated plant; 3 - OsPHI-30 gene of control plant; 4 - OsPHI-30 gene of salt-treated plant; 5 - OsPHI-147 gene of control plant; 6 - OsPHI-147 gene of salt-treated plant; 7 - OsPHI-928 gene of control plant; 8 - OsPHI928 gene of salt-treated plant

Table 8: Relative expression of some identified up-regulated genes of OsPHI library at Phase II of salt-stress development

\begin{tabular}{lcc}
\hline $\begin{array}{c}\text { Genes amplified from } \\
\text { control and salt treated } \\
\text { plants of Phase II }\end{array}$ & $\begin{array}{c}\text { Average } \\
\text { pixel value }\end{array}$ & $\begin{array}{c}\text { Expression relative } \\
\text { to reference gene } \\
\text { (Tubulin) }\end{array}$ \\
\hline Control - Tubulin & 81.27 & 1 \\
Salt stress - Tubulin & 86.47 & 1 \\
Control - OsPHI-30 & 69.27 & 0.85 \\
Salt stress - OsPHI-30 & 71.98 & 0.83 \\
Control - OsPHI-147 & 72.37 & 0.89 \\
Salt stress - OsPHI-147 & 61.06 & 0.70 \\
Control - OsPHI-928 & 64.31 & 0.79 \\
Salt stress - OsPHI-928 & 63.60 & 0.73 \\
\hline
\end{tabular}

salt treated plants than in untreated plants. Therefore, this experiment and the experiment on dot blot analysis revealed that OsPHI-30, OsPHI-147 and OsPHI-928 are contributing as up-regulating genes to tolerate osmotic stress in variety At354. The existence and level of expression of these genes were checked during Phase II as well. The results showed that none of the three genes that were tested showed up-regulation during Phase II (Table 8).
Table 7: Relative expression of some identified up-regulated genes of OsPHI library at Phase I of salt-stress development

\begin{tabular}{lcc}
\hline $\begin{array}{c}\text { Genes amplified from } \\
\text { control and salt-treated } \\
\text { plants of Phase I }\end{array}$ & $\begin{array}{c}\text { Average } \\
\text { pixel value }\end{array}$ & $\begin{array}{c}\text { Expression relative } \\
\text { to reference gene } \\
\text { (Tubulin) }\end{array}$ \\
\hline Control -Tubulin & 105.24 & 1 \\
Salt stress -Tubulin & 82.90 & 1 \\
Control - OsPHI-30 & 86.9 & 0.82 \\
Salt stress - OsPHI-30 & 72.91 & 0.88 \\
Control - OsPHI-147 & 74.03 & 0.70 \\
Salt stress - OsPHI-147 & 69.8 & 0.84 \\
Control - OsPHI-928 & 67.08 & 0.64 \\
Salt stress - OsPHI-928 & 64.47 & 0.78 \\
\hline
\end{tabular}

\section{DISCUSSION}

Probable involvement of the up- and down-regulated genes in the salt tolerance of variety At354 during phase I

Genes up-regulated in At354 in response to salt stress during Phase I

The cDNA Clone No.OsPHI-30 showed $75 \%$ identity with a nucleotide sequence, which has been identified from the Japonica rice variety Nipponbare, and expressed under salt stress. At present, no further information is available in databases on this gene to deduce its possible physiological role in conferring salt tolerance.

The cDNA fragment of Clone No.OsPHI-32 from salt-stressed At354 is homologous to an eukaryotic translation initiation factor eIF5A. This factor, formerly called eIF-4D, is the only cellular protein known to contain the unusual amino acid hypusine and is known to accumulate in rice in response to salt and heavy metal stress (Chou et al., 2004). During salt stress development, salt ion toxicity is initially experienced by the older leaves, which are unable to dilute incoming salts by expanding. Hence, OseIF5A expressed in salt stressed At354 may play a role in protecting rice leaves from salt ion toxicity. Although in the present study, up-regulation of OseIF5A has been observed during Phase I of salinity 
where salt toxicity is not expected to be significant, the high salt sensitivity of rice (Grattan et al., 2002; Munns and Tester, 2008) may mean that salt toxicity has already begun in Phase I. This was confirmed by measurements of tissue $\mathrm{Na}^{+}$concentrations in old and young leaf tissues in the present experiment (data not shown). Being more abundant in older leaves, OseIF5A may be contributing to $\mathrm{Na}^{+}$exclusion from younger leaves by helping in the transport of excess $\mathrm{Na}^{+}$to the vacuole of older leaves. Alternatively, through its expression in panicles and older leaves, OseIF5A may be contributing to a protective function from salinity. OseIF5A plays an important role in the determination of cell proliferation and death in eukaryotic cells (Thompson et al., 2004). As expression of eIF5A in rice is high in older leaves (Chou et al., 2004), it could contribute to keep older leaves alive under salt stress by increasing their tissue tolerance to salt ion toxicity.

The cDNA Clone No. OsPHI-33 gave homology to cytochrome oxidase I of mitochondria. The mitochondria are sensitive to salt stress. Mitochondrial function is required for proper salt and osmotic stress adaptation because mutants with defects in many different mitochondrial components show hypersensitivity to increased $\mathrm{NaCl}$ concentrations. Cytochrome oxidase I is needed to activate mitochondria to adapt for osmotic stress (Pastor et al., 2009). It can function via general metabolism to reduce salt stress in rice plants (Sahi et al., 2006a) and hence its up-regulation in At354 during Phase I of salt stress may activate mitochondria to adapt to osmotic stress.

One effective mechanism to reduce damage from salt stress is the accumulation of high intracellular levels of osmoprotectant compounds (Munns, 2005). The cDNA Clone No.OsPHI-147 from salt stressed At354 was homologous to a gene of Oryza sativa which produces a putative serine decarboxylase, an enzyme needed to produce ethanolamine, a precursor of choline (McNeil et al., 2001). Choline is needed to produce glycinebetaine (Huang et al., 2000), which acts as an osmoprotectant conferring salt tolerance in plants (Blumwald et al., 2004). Hence, the gene products of this cDNA clone could be providing a protective function, primarily from osmotic stress that occurs during Phase I.

DNA and protein homology search showed that cDNA Clone No. OsPHI-194 from salt stressed At354 is homologous to a gene similar to LSTK-1-like kinase of Oryza sativa Japonica Nipponbare rice variety. LSTK-1like kinase enzyme is expressed in maize plants exposed to drought stress (Li et al., 2009). As drought, induced by osmotic stress, is the major stress that operates during Phase I of salt stress development, up-regulation of clone 194 in At354 provides evidence that it may be coding for a gene product that is responsible for osmotic stress tolerance.

The cDNA Clone No OsPHI-240 from salt-stressed At354 gave homology to WD40-like domain containing protein. This protein functions via regulatory pathway to tolerate osmotic stress (Lee et al., 2010).

The cDNA Clone No. OsPHI- 928 from salt-stressed At354 gave homology to a putative gene of Oryza sativa that produces the AP domain DRE (dehydration responsive elements) binding factor. The DRE-related motifs are at promoter regions of many cold and drought inducible genes (Dubouzet et al., 2003). Overexpression of these regulatory elements, which are transcription factors, increases drought (Chen et al., 2008; Kumashiro \& Yamaguchi-Shinozaki, 2008), salt and low temperature tolerance (Wang et al., 2008). Promoter regions of most genes induced by drought, salinity and cold in rice are enriched with two DRE transcription factors, the ABAindependent DRE and the ABA-responsive ABRE (Zhou et al., 2007). Comparison of expression profiles for several stresses showed that there was considerable overlap between profiles induced by drought, salinity and $A B A$ treatment. Therefore, it is logical that the gene product of this particular cDNA clone is up-regulated in the salt-tolerant rice genotype At354 during Phase I of salt stress, which is dominated by osmotic stress-induced drought.

Homology search elucidated that the cDNA Clone No. OsPHI- 941 is similar to zinc finger protein 1- like isoform. Several zinc finger proteins have previously been identified in rice (Huang et al., 2005; Huang et al., 2007; Xu et al., 2008) under different abiotic stresses. It enhances the activities of reactive oxygen speciesscavenging enzymes under stress conditions and increases the tolerance of plants to oxidative stress, which can be caused by the osmotic stress that prevails during Phase I of salt stress.

OsPHI-1271 was identified as an up-regulated cDNA clone due to salt-stress in At 354. The transcripts carried by this clone were homologous to a putative gene, which produces a chromosomal replication initiator protein of Pectobacterium wasabiae. There have been no reports on the possible involvement of this gene product in stress tolerance in plants. 
Homology search on the cDNA Clone Nos. OsPHI- 2277 and OsPHI-2465 showed more than $95 \%$ identity with ESTs of water stressed durum wheat. Thus, they may also be involved in osmotic tolerance of variety At 354 .

The cDNA Clone No. OsPHI-2468 gave homology to a hypothetical protein of Oryza sativa. There have been no reports of the possible involvement of these protein products in salt stress tolerance in plants.

Activating antioxidative systems to avoid salt stress is a mechanism of salt tolerance. Clone OsPHI-2470 gave homology to a gene product, which is similar to receptor-like kinase protein (RLK) of Oryza sativa. RLKs play essential roles in plant growth, development and responses to environmental stresses and are activated during salt- and drought stress tolerance in rice, through the activation of antioxidant systems (Ouyang et al., 2010). Thus, the protein, which is similar to RLK in At354 may activate antioxidative systems to tolerate osmotic stress.

The cDNA Clone No. OsPHI- 2487, which was upregulated gave homology to a gene that produces a SET domain-containing protein expressed in roots of drought tolerant upland rice variety Prata Ligeiro (Rabello et al., 2008). As drought is the principal stress factor operating during Phase I of salt stress, it is possible that this protein may be involved in salt tolerance of At354 during Phase I.

\section{Genes down-regulated in At354 in response to salt stress during Phase 1}

The cDNA Clone No. OsPHI-42 gave homology to an aldo-keto reductase family protein of Oryza sativa. Kim et al. (2011) found that aldo-keto reductase was downregulated in the rice variety Nipponbare, 6 days after experiencing a salt-stress of $130 \mathrm{mM}$. Down-regulating a metabolic pathway, which causes damage due to osmotic stress by this gene is possible. Hence, its down-regulation increases tolerance to osmotic stress during Phase I of salt-stress development.

Under $\mathrm{NaCl}$ stress, plants decrease energy metabolism rates to conserve energy and limit further generation of reactive oxygen species (ROS) (Moller, 2001), which can cause damage to cellular components during abiotic stress. The cDNA Clone No. OsPHI-54 obtained from salt-stressed At354 was homologous to a gene of Oryza sativa, which produces a protein similar to enolase. Jiang et al. (2007) found that phosphopyruvate hydratase/enolase (LOS2, At2g36530), which catalyses the formation of high-energy phosphoenol pyruvate from 2-phosphoglycerate in the glycolytic pathway, decreased in response to $\mathrm{NaCl}$ stress in roots of Arabidopsis. Therefore, the observation in the present study that enolase is down-regulated during early phase of salt stress in variety At354 indicates that this enzyme may play a role in decreasing energy metabolism rates to conserve energy and limit further generation of ROS and thereby tolerate osmotic stress during Phase I of saltstress development.

The cDNA Clone Nos. OsPHI-154 and OsPHI841 gave more than $80 \%$ identity with a hypothetical protein of Arabiodopsis lyrata sub sp. There have been no reports of the possible involvement of these protein products in salt stress tolerance in plants. This may show the involvement of novel genes, whose functions are yet to be elucidated.

The cDNA fragments of Clone Nos. OsPHI172, OsPHI-864, OsPHI-1142 and OsPHI-2806 were identified as down-regulated genes during Phase I of saltstress. These were found to have more than $85 \%$ identity to a hypothetical protein of the cultivar Nipponbare of Oryza sativa. There have been no reports of the possible involvement of these gene products in stress tolerance in rice. Therefore, it is possible that these genes are coding for novel proteins responsible for osmotic stress tolerance in rice.

Homology search elucidated that the cDNA Clone No OsPHI- 181 is similar to Beta-amyrin synthase of Oryza sativa. No information is available on physiological functions of this gene product in stress tolerance in rice.

The cDNA Clone Nos. OsPHI-183 and OsPHI-939 gave homology to a protein similar to 30S Ribosomal protein S18. A decrease in bulk de novo protein synthesis following $\mathrm{NaCl}$ treatment has been detected in Arabidopsis by Ndimba et al. (2005). Also, Jiang et al. (2007) showed that the synthesis of three ribosomal proteins was decreased by $\mathrm{NaCl}$ treatment in Arabidopsis. They suggested that short-term $\mathrm{NaCl}$ stress may repress protein synthesis in vivo. Thus, downregulation of ribosomal proteins in variety At354 during Phase I of salt-stress may also contribute to regulated gene expression by suppressing bulk protein synthesis.

The protein homology search showed that cDNA fragments harboured by the Clone Nos. OsPHI-230 and OsPHI-2792, which have been identified as downregulating genes in the present study encode for amine oxidases. Amine oxidases catalyze the oxidative deamination of polyamines (Cona et al., 2006), which are an important group of compounds regulating 
plant responses to various stresses such as salinity, drought, low temperature and ozone (Liu et al., 2007). Overexpression of polyamine biosynthesis could lead to abiotic stress tolerance via stabilization of negativelycharged molecules such as proteins and membrane lipids, reduction of free radicals by anti-oxidant properties and improvement of ionic balance (Liu et al., 2007). By down-regulating genes encoding for polyamine degradation, gene products of cDNA Clone Nos. 230 and 2792 obtained from salt-stressed At354 are likely to reduce polyamine degradation during salt stress, thereby allowing the stress tolerance functions of polyamines to operate. This could contribute to the salt tolerance of At354 in Phase I of salinity. Furthermore, polyamine degradation produces $\mathrm{H}_{2} \mathrm{O}_{2}$, which mediates cell death and thereby increases stress sensitivity. Downregulation of genes that trigger the above process would also contribute to the stress tolerance of At354.

The cDNA Clone No. OsPHI- 719 was downregulated during Phase I of salt stress. This clone gave homology to a protein, which is similar to photosystem II P680 chlorophyll A apoprotein (CP-47 protein). Photosystem II is responsible for capture of radiation for photosynthesis. However, osmotic stress during Phase I of salt-stress probably reduces the demand for radiation energy because of reduced photosynthesis under osmotic stress. Hence, down-regulation of the expression of a gene, which is responsible for a protein linked to photosystem II may indicate a response to reduce radiation absorption and reduce the energy load in the chloroplasts. Such a reduction in the energy load would prevent photoinhibitory damage due to the formation of reactive oxygen species (ROS).

The cDNA Clone No. OsPHI-937 showed $83 \%$ identity to an EST of the panicle of Pistacia vera. There have been no reports of the possible involvement of these ESTs in stress tolerance in plants. However, it is possible that down-regulation of this gene in salt-stressed At354 could be responsible for delaying of panicle development during the period of osmotic stress. Such a delay in panicle development would be advantageous to the rice plant because water stress during Phase I of salt-stress development would have adverse effects on several sub-processes of panicle development leading to the formation of sterile grains. Therefore, downregulation of this gene could be part of a mechanism of stress avoidance, which probably contributes to the salt tolerance of At354.

The cDNA fragment harboured by Clone No. OsPHI- 2805 from salt-stressed At354 was homologous to a protein product of rap-GTPase-activating protein, which is needed to activate the cyclic neucleotide pathway in mammals. Although the presence of cyclic neucleotides (i.e. 3',5'-cyclic adenyl monophosphate, cAMP, and 3',5'-cyclic guanyl monophosphate, cGMP) and their functional roles have been well-established in animal cells, their presence in plant cells have been confirmed only recently (Newton \& Smith, 2004; Martinez-Atienza et al., 2007). Cyclic neucleotides have been implicated in the signalling and regulation of many important plant processes such as stomatal functioning, cation fluxes, chloroplast development, gibberellic acid signalling, pathogen response and gene transcription (Martinez-Atienza et al., 2007). There are several reports of evidence indicating a role for cAMP and/or cGMP in stomatal opening (Newton \& Smith, 2004). Results of the present study have shown a down-regulation of a gene product (i.e. rap-GTPase-activating protein), which is responsible for activation of the cyclic neucleotide pathway in At354 during Phase I of salt stress. As osmotic stress induced water deficits are the main effect of salinity during Phase I, partial stomatal closure by down-regulating the cyclic neucleotide pathway may help alleviate adverse effects of water stress and thereby contribute to salt-tolerance of At354 in Phase I.

There is evidence of direct effects of cyclic neucleotides on intra-cellular cation fluxes raising the possibility of a role in regulating the homeostasis of $\mathrm{K}^{+}$, $\mathrm{Ca}^{2+}$ and $\mathrm{Na}^{+}$ions (Maathuis, 2006). Ion homeostasis involves maintaining cytoplasmic ratios of $\mathrm{K}^{+}: \mathrm{Na}^{+}$and $\mathrm{Ca}^{2+}: \mathrm{Na}^{+}$within optimum ranges. This may require both increases and decreases of the uptake of these cations in plants experiencing salt stress. Therefore, it is possible that down-regulation of the cyclic neucleotide pathway in salt-stressed At354 during Phase I may contribute to maintenance of cytoplasmic ion homeostasis.

The cDNA Clone No. OsPHI-2855 from saltstressed At354 was homologous to agmatine deiminase protein product, which is an enzyme in the biosynthesis pathway of putrescine, an important member of the polyamine group (Gill \& Tuteja, 2010). It has already been noted that polyamines can play an important role in stress tolerance as stress messengers in plant responses to different stress signals (Alcázar et al., 2006, 2010). Interestingly, Zapata et al. $(2003,2004)$ observed on a range of vegetable crops that salt stress decreased tissue putrescine (Put) levels while increasing the levels of the other two polyamines, spermidine (Spd) and spermine $(\mathrm{Spm})$ so that the ratio $(\mathrm{Spd}+\mathrm{Spm}) /$ Put was increased. They further observed that salt tolerance increased with the above concentration changes in different polyamines. In a comparative study with six crop species differing in salt tolerance, Zapata et al. (2008) showed that Put 
concentration in shoot was negatively correlated with salt tolerance of the species, with the most tolerant species (Beta vulgaris) having the lowest shoot Put concentration. Similarly, in a screening of nine rice cultivars differing in salt tolrance, Krishnamurthy and Bhagwat (1989) observed significant increases in Spd and Spm in salt tolerant cultivars, but no significant alteration in Put when subjected to salt stress. In contrast, the saltsensitive cultivars showed an excessive accumulation of Put under salt stress but Spd and Spm concentrations remained low. Therefore, the observed down-regulation of the gene product responsible for biosynthesis of Put in the salt tolerant At354 under salinity in the present study probably contributed to its salt tolerance. This finding is in agreement with the observations of Zapata et al. (2004) and Krishnamurthy and Bhagwat (1989).

Probable involvement of the up-and down- regulated genes in the salt tolerance of variety At354 during Phase II

Genes up-regulated in At354 in response to salt stress during Phase II

In the present study, the cDNA Clone No. OsPHII-1 from OsPHII library was similar to dicarboxylate transporters, which are needed to mediate the counterexchange of malate, glutamate and aspartate (Flügge et al., 1988). Transport of malate into the vacuole and its subsequent storage are essential in stomatal opening (Emmerlich et al., 2003). Thus, up-regulation of the above transporter gene during ionic stress, which is the principal stress during Phase II of salt-stress development may increase malate transport ability to the vacuole and thereby maintain the osmotic pressure, charge balance and regulate stomatal aperture to maintain photosynthesis under salt stress.

One important aspect of tolerance to ionic stress is the ability to transfer the toxic $\mathrm{Na}^{+}$and $\mathrm{Cl}^{-}$ions to the vacuole. In order to maintain ionic balance in the vacuole, compatible solutes such as malate, glutamate and aspartate also have to be transferred to the vacuole. Therefore, the dicarboxylate transporters encoded by the cDNA Clone No. OsPHII-1 probably play an important role in intracellular compartmentation of excess salts in the vacuole. As such, up-regulation of the genes responsible for dicarboxylate transporters probably contributes to the salt-tolerance of At354 in Phase II of salt stress development.

The cDNA fragment of Clone No. OsPHII-11 gave homology to DRE-binding protein of Zea mays, whose role in salt tolerance was discussed earlier (Zhou et al., 2007; Wang et al., 2010). The cDNA Clone Nos. OsPHII-51 and OsPHII-133 showed identity with heat shock protein (HSP81-1) / (HSP83) of Zea mays. Many studies have shown that involvement of heat shock protein in regulatory mechanisms to tolerate salt stress (Sahi et al., 2006b). Hence, up-regulation of this protein during Phase II probably contributed to the salt tolerance of At354.

The cDNA Clone Nos. OsPHII-77 and OsPHII370 which have been identified as up-regulated genes of OsPHII library in our study, showed more than $92 \%$ identity to a hypothetical protein of the cultivar Nipponbare of Oryza sativa. However, no reports are available of the possible involvement of these protein products in salt stress tolerance in plants.

Clone No. OsPHII-151 gave homology to a precursor of peroxidise, which has the ability to scavenge ROS such as $\mathrm{H}_{2} \mathrm{O}_{2}$ (Huang et al., 2009), thus contributing to salt tolerance of At354. This finding reveals that variety At354 has the ability to eliminate ROS production by upregulating ROS scavengers.

Protein degradation during stress is a highly conserved and regulated phenomenon in all the organisms reported so far (Vierstra \& Callis, 1999). Genes encoding proteins like ubiquitin ligase, polyubiquitin, proteasome subunit, and protease inhibitor are known to be expressed in the cDNA libraries of stressed tissues (Mahalingam et al., 2003). The up-regulated Clone No. OsPHII- 331 of the present study showed homology to ubiquitin-protein ligase, which probably contributed to the Phase II salt tolerance of At354 via protein turnover.

The cDNA fragment harboured by Clone No. OsPHII-311 obtained from OsPHII was homologous to MADs box protein of Oryza sativa. Cooper et al. (2003) showed that MADS box TFs are important components of salt stress networking in plants and their possible role during stress is transcriptional regulation of stress gene expression.

Different molecules have been shown to act as signals in the stress-associated signal transduction processes. Changes in cytosolic $\mathrm{Ca}^{2+}$ concentrations act as a second messenger in salt stress (Chinnusamy et al., 2005). The present study revealed that up-regulation of the cDNA fragment from Clone No. OsPHII-373 encodes for EFhand containing protein, which is likely to be one of the key transducers mediating $\mathrm{Ca}^{2+}$ action.

The cDNA fragment harboured by Clone No. OsPHII-590 gave identity to harpin-inducing protein, 
which activates cellular events of transcription regulation, signal transduction, stress response, membrane transporting, photosynthesis and cell wall biosynthesis (Chuang et al., 2010). Overexpression of ethyleneresponse factor 5 (designated as SlERF5), which is a harpin-induced protein, in Arabidopsis thaliana activated a large number of genes involved in signaling pathways of disease resistance, abiotic stress response and protein phosphorylation. Thus, harpin probably plays similar roles in At354 also and thereby contributes to its salttolerance during Phase II.

\section{Genes down-regulated in At354 in response to salt stress during Phase II}

The cDNA Clone No. OsPHII-159, which has been identified as a down-regulated gene of OsPHII library in the present study gave $88 \%$ identity to a hypothetical protein of Nipponbare cultivar of Oryza sativa. There have been no reports of the possible involvement of these protein products in salt stress tolerance in plants. This may show the involvement of novel genes, whose functions are yet to be elucidated.

The cDNA fragment of Clone No. OsPHII-333 from OsPHII was down-regulated under salt-stress and it gave identity to $\mathrm{KN}$ motif and ankyrin repeat domains of Ciona intestinalis. Down-regulation of ankyrin repeat-containing protein AKR2 of Arabidopsis increased transcripts of genes encoding pathogeninduced protein PR-1 (pathogen-related protein 1) and stress-responsive protein glutathione S-transferase 6 (GST6) (Yan et al., 2002). Glutathione peroxidase (GSH)-dependent peroxidase reactions protect cell components from oxidative damage by scavenging toxic organic hydroperoxides. Also, plant GSTs play a role in GSH-dependent thioltransferase that safeguards protein function from oxidative damage, and are also involved in dehydroascorbate reductase (DHAR) that functions in redox homeostasis. Moreover, plant GSTs play an indirect role in the regulation of apoptosis and in stress signaling pathways (Dixon et al., 2002; Frova, 2003). Over-expression of the glutathione $S$-transferase gene contributes to the antioxidation function and thereby increases stress tolerance of plants (Katsuhara et al., 2005; Diao et al., 2010). Therefore down - regulation of the Clone No. OsPHII-333 encoding protein may increase gluthathione S-transferase activity during Phase II of At354 and contribute to its salt-tolerance.
Confirmation of differential expression of identified candidate genes of OsPHI and OsPHII libraries by dot blot analysis and comparative expression analysis of some selected genes by relative RT-PCR

Up-regulated salt tolerant genes are expected to produce more mRNA transcripts in order to produce high quantities of functional proteins under salt stress. Therefore, more mRNA transcripts can be expected within total cellular RNA of up-regulated genes than that of down-regulated genes that produce less transcripts. Hence, dot blot analysis confirmed the differential expression of the identified candidate genes of salt tolerance during Phases I and II.

Relative RT-PCR uses standard PCR techniques but permits the comparison of transcript quantities between samples by co-amplifying the gene of interest with a housekeeping gene that acts as an internal control (reference gene). In comparison to northern blots, relative RT-PCR is much more sensitive and requires much less RNA (Dean et al., 2002). $\alpha$-tubulin gene has been used as a reference gene for rice in several studies (Caldana et al., 2007; Yadav et al., 2012) and the homogeneity of $\alpha$-tubulin gene expression under normal and salinity stress conditions has been tested previously (Yadav et al., 2012). In the quantification of relative RT-PCR, expression of the gene of interest is compared with the $\alpha$-tubulin gene that was expressed under the given treatment condition (i.e. salt treated or control condition). Hence, despite slight variations in the expression of some reference genes (which have been observed with some of the reference genes due to variations in template concentration and PCR amplification efficiency (Dean et al., 2002), the normalization of gene expression at a given condition will not be affected. Although the three genes selected for the relative RT-PCR study contributed significantly to the osmotic tolerance of At354 during Phase I (Table 7), they did not contribute significantly to tolerance of salt ion toxicity during Phase II (Table 8).

\section{Concluding remarks}

Results of the present study clearly demonstrated that osmotic stress during Phase I and ionic stress during Phase II caused changes in the expression of several genes in the shoots of the salt tolerant Sri Lankan rice variety At354. In addition, 25 up-regulated and 19 down-regulated differentially - expressed genes in At354 belonging to a variety of functionality classes such as 
Table 9: Summary of up-regulated genes/ probable proteins produced by variety At354 during Phase I and Phase II of salt-stress development to tolerate salt stress

\begin{tabular}{ll}
\hline $\begin{array}{l}\text { Up-regulated candidate genes/ probable proteins } \\
\text { responsible for salt tolerance during Phase I }\end{array}$ & $\begin{array}{l}\text { Up-regulated candidate genes/ probable proteins } \\
\text { responsible for salt tolerance during Phase II }\end{array}$ \\
\hline Eukaryotic translation initiation factor eIF5A & Dicarboxylate transporters \\
Cytochrome oxidase I of mitochondria & Heat shock protein(HSP81-1)/(HSP83) \\
Putative serine decarboxylase & Peroxidise precursor \\
LSTK-1-like kinase & Ubiquitin-protein ligase \\
AP domain DRE binding factor & Hypothetical protein of Oryza sativa \\
WD40-like domain containing protein & MADs box protein \\
Chromosomal replication initiator protein & EF-Hand type domain containing protein \\
Similar to receptor-like kinase protein & Dehydration responsive element binding protein \\
Zinc finger protein 1- like isoform & Harpin inducing protein \\
SET domain protein & \\
Similar to EST of water stressed durum wheat & \\
Putatively expressed salt-tolerant gene & \\
Hypothetical protein of Oryza sativa & \\
\hline
\end{tabular}

Table 10: Summary of down-regulated genes/ probable proteins produced by variety At354 during Phase I and Phase II to tolerate salt stress

\begin{tabular}{ll}
$\begin{array}{l}\text { Down-regulated candidate genes/ probable proteins responsible } \\
\text { for salt tolerance during Phase I }\end{array}$ & $\begin{array}{l}\text { Down-regulated candidate genes/ probable proteins } \\
\text { responsible for salt tolerance during Phase II }\end{array}$ \\
\hline Enolase (2phosphoglycerate dehydratase) & KN motif and ankyrin repeat domains protein \\
Aldo keto reductase family protein & Hypothetical protein of Oryza sativa \\
Beta-amyrin synthase & \\
30 S Ribosomal protein S18 & \\
Amine oxidases & \\
Photosystem II P680 chlorophyll A apoprotein (CP-47 protein) \\
Similar to EST found in male and female panicle of Pistacia vera \\
Agmatine deiminase \\
Rap-GTPase-activating protein \\
Hypothetical protein
\end{tabular}

protein synthesis, folding and stabilization (4 genes), general metabolism (4 genes), transcription (4 genes), signal transduction (3 genes), cellular redox balance (5 genes), cellular transport/homeostasis (4 genes) and defence-related functions ( 3 genes) have been identified. Out of the remaining differentially - expressed genes, ten genes belonged to hypothetical proteins and seven genes are of unknown functions. 


\section{Acknowledgement}

Financial assistance provided by the International Centre for Genetic Engineering and Biotechnology (ICGEB), Italy (Grant Ref. No. CRP/SRI06-01) and the National Science Foundation of Sri Lanka (Grant No.: SIDA/2007/ BT/01) is gratefully acknowledged.

\section{REFERENCES}

1. Alcázar R., Altabella T., Marco F., Bortolotti C., Reymond M., Koncz C., Carrasco P. \& Tiburcio A.F. (2010). Polyamines: molecules with regulatory functions in plant abiotic stress tolerance. Planta 231: 1237 - 1249.

2. Alcázar R., Marco F., Cuevas J.C., Patron M., Ferrando A., Carrasco P., Tiburcio A.F. \& Altabella T. (2006). Involvement of polyamines in plant response to abiotic stress. Biotechnology Letters 28: 1867 - 1876.

3. Ashraf M. \& Akram N.R. (2009). Improving salinity tolerance of plants through conventional breeding and genetic engineering: an analytical comparison. Biotechnology Advances 27: 744 - 752.

4. Blumwald E., Grover A. \& Good A.G. (2004). Breeding for abiotic stress resistance: challenges and opportunities. $4^{\text {th }}$ International Crop Science Congress/ Australian Agronomy Conference 2004: Symposia 3 (6) Adaptation to Abiotic Challenges. Brisbane, Australia. available at $h t t p: / /$ www.regional.org.au/au/asa/2004/ symposia/3/6/1953 blumwalde.htm, Accessed 20 May 2012.

5. Caldana C., Scheible W.R., Mueller-Roeber B. \& Ruzicic S. (2007). A quantitative RT-PCR platform for highthroughput expression profiling of 2500 rice transcription factors. Plant Methods 3:7.

6. Chen J.Q., Meng X.P., Zhang Y., Xia M. \& Wang X.P. (2008). Over-expression of OsDREB genes lead to enhanced drought tolerance in rice. Biotechnology Letters 30: $2191-2198$.

7. Chinnusamy V., Jagendorf A. \& Zhu J.K. (2005). Understanding and improving salt tolerance in plants. Crop Science 45 (2): 437 - 448.

8. Chou W.C., Huang Y.W., Tsay W.S., Chiang T.Y., Huang D.D. \& Huang H.J. (2004). Expression of genes encoding the rice translation initiation factor, eIF5A, is involved in developmental and environmental responses. Physiologia Plantarum 121 (1): 50 - 57.

9. Chuang H., Harnrak A., Chen Y. \& Hsu C. (2010). A harpin-induced ethylene-responsive factor regulates plant growth and responses to biotic and abiotic stresses. Biochemical and Biophysical Research Communications 402 (2): $414-420$.

10. Cona A., Rea G., Angelini R., Federico R. \& Tavladoraki P. (2006). Functions of amine oxidases in plant development and defence. Trends in Plant Science 11: $80-88$.

11. Cooper B., Clarke J.D. \& Budworth P. (2003). A network of rice genes associated with stress response and seed development. Proceedings of the National Academy of Sciences, USA 100 (8): 4945 - 4950.

12. Dean J.D., Goodwin P.H. \& Hsiang T. (2002). Comparison of relative RT-PCR and northern blot analyses to measure expression of $\beta$-1, 3-glucanase in Nicotiana benthamiana infected with Colltotrichum destructivum. Plant Molecular Biology Reporter 20: 347 - 356.

13. De Costa W.A.J.M., Wijeratne M.A.D., De Costa D.M. \& Zahra A.R.F. (2012). Determination of the appropriate level of salinity for screening of hydroponically grown rice for salt tolerance. Journal of the National Science Foundation of Sri Lanka 40(3):123 - 136.

14. Diao G., Wang Y. \& Yang C. (2010). Functional characterization of a gluthathione S-transferase gene from Limonium bicolor in response to several abiotic stresses. African Journal of Biotechnology 9 (32): 5060 -5065 .

15. Dixon D.P., Lapthorn A. \& Edwards R. (2002). Plant glutathione transferases. Genome Biology 3: 3004.1 3004.10 .

16. Dubouzet J.G., Sakuma Y., Ito Y., Kasuga M., Dubouzet E.G., Miura S., Seki M., Shinozaki K. \& YamaguchiShinozaki K. (2003). OsDREB genes in rice, Oryza sativa L., encode transcription activators that function in drought-, high-salt- and cold-responsive gene expression. Plant Journal 33 (4): 751 - 763.

17. Emmerlich V., Linka N., Reinhold T., Hurth M.A., Traub M., Martinoia E. \& Neuhaus H.E. (2003). The plant homolog to the human sodium/dicarboxylic cotransporter is the vacuolar malate carrier. Proceedings of the National Academy of Sciences, the USA 100 (19): 11122 - 11126.

18. Flügge U.I., Woo K.C. \& Heldt H.W. (1988). Characteristics of 2-oxoglutarate and glutamate transport in spinach chloroplasts. Planta 174 (4): $534-541$.

19. Frova C. (2003). The plant glutathione transferase gene family: Genomic structure, functions, expression and evolution. Physiologia Plantarum 119 (4): $469-479$.

20. Gause W.C. \& Adamovicz J. (1995). Use of PCR to quantitate relative differences in gene expression. $P C R$ Primer: A Laboratory Manual (eds. C.W. Dieffenbach \& G.S. Dveksler), pp. 293 - 311. Cold Spring Harbor Laboratory Press, Cold Spring Harbor, New York, USA.

21. Gill S.S. \& Tuteja N. (2010). Polyamines and abiotic stress tolerance in plants. Plant Signalling and Behaviour 5: $26-33$.

22. Grattan S., Zeng L., Shannon M. \& Roberts S. (2002). Rice is more sensitive to salinity than previously thought. California Agriculture 56: 189 - 198.

23. Huang J., Hirji R., Adam L., Rozwadowski K.L., Hammerlindl J.K., Keller W.A. \& Selvaraj G. (2000). Genetic engineering of glycinebetaine production towards enhancing stress tolerance in plants: metabolic limitations. Plant Physiology 122: $747-756$.

24. Huang J., Wang J.F., Wang Q.H. \& Zhang H.S. (2005). Identification of a rice zinc finger protein whose expression is transiently induced by drought, cold but not by salinity and abscisic acid. DNA Sequence 16:130 - 136.

25. Huang J., Yang X., Wang M.M., Tang H.J., Ding L.Y., Shen Y. \& Zhang H.S. (2007). A novel rice C2H2-type zinc finger protein lacking DLN-box/EAR-motif plays a role in salt tolerance. Biochimica et Biophysica Acta 1769: $220-227$. 
26. Huang J., Chao Y. \& Gao P. (2009). A previously unknown zinc finger protein, DST, regulates drought and salt tolerance via stomatal aperture control. Genes and Development 23 (15): $1805-1817$.

27. Jiang Y., Yang B., Harris N.S. \& Deyholos M.K. (2007). Comparative proteomic analysis of $\mathrm{NaCl}$ stress-responsive proteins in Arabidopsis roots. Journal of Experimental Botany 58 (13): 3591 - 3607.

28. Kafatos F.C., Jones W.C. \& Efstratiadis A. (1979). Determination of nucleic acid sequence homologies and relative concentration by dot blot hybridization procedure. Nucleic Acids Research 7: 1541 - 1552.

29. Katsuhara M., Otsuka T. \& Ezaki B. (2005). Salt stress-induced lipid peroxidation is reduced by glutathione $S$-transferase, but this reduction of lipid peroxides is not enough for a recovery of root growth in Arabidopsis. Plant Science 169 (2): 369 - 373.

30. Kawasaki S., Borchert C., Deyholos M., Wang H., Brazille S., Kawai K., Galbraith D. \& Bohnert H.J. (2001). Gene expression profiles during the initial phase of salt stress in rice. Plant Cell 13: 889 - 905.

31. Kim D.W., Shibato J.G.K., Agrawal H., Iwahashi D.H., Kim I.S., Shim S \& Rakwal R. (2011). Functional categorization of salt stress-responsive genes of rice leaf using DNA microarray. Rice Genetics Newsletter Vol. 23. available at http://www.shigen.nig.ac.jp/rice/oryzabase/ rgn/pdf/23_19.pdf, Accessed 20 May 2012.

32. Krishnamurthy R. \& Bhagwat K.A. (1989). Polyamines as modulators of salt tolerance in rice cultivars. Plant Physiology 91 (2): 500 - 504.

33. Kumashiro T. \& Yamaguchi-Shinozaki K. (2008). Research activities on drought tolerance of rice at JIRCAS. Drought Frontiers in Rice: Crop Improvement for Increased Rainfed Production (eds. R. Serraj, J. Bennett \& B. Hardy), pp. 325 - 332, International Rice Research Institute, Los Banos, The Philippines.

34. Lee S., Lee J., Paek K., Kwon S., Cho S.H., Kim S.J. \& Park J.M. (2010). A novel WD40 protein, BnSWD1, is involved in salt stress in Brassica napus. Plant Biotechnology Report 4: 165 - 172.

35. Li Y., Sun C., Huang Z., Pan J., Wang L. \& Fan X. (2009). Mechanisms of progressive water deficit tolerance and growth recovery of Chinese Maize Foundation Genotypes Huangzao 4 and Chang 7-2, which are proposed on the basis of comparison of physiological and transcriptomic Responses. Plant and Cell Physiology 55: 1648 - 1660.

36. Liu J.H., Kitashiba H., Wang J., Ban Y. \& Moriguchi T. (2007). Polyamines and their ability to provide environmental stress tolerance to plants. Plant Biotechnology 24: $117-126$.

37. Maathuis F.J.M. (2006). cGMP modulates gene transcription and cation transport in Arabidopsis roots. Plant Journal 45 (5): 700 - 711.

38. Mahalingam R., Gomez-Buitrago A., Eckardt N., Shah N., Guevara-Garcia A., Day P., Raina R. \& Fedoroff N.V. (2003). Characterizing the stress/defense transcriptome of Arabidopsis. Genome Biology 4 (3): R20.1 - R20.14.

39. Martinez-Atienza J., Ingelgem C.V., Roef L. \& Maathuis F.J.M. (2007). Plant cyclic nucleotide signaling: facts and fiction. Plant Signalling and Behaviour 2 (6): 540 543.

40. McNeil S.D., Nuccio M.L., Ziemak M.J. \& Hanson A.D. (2001). Enhanced synthesis of choline and glycine betaine in transgenic tobacco plants that overexpress phosphoethanolamine $\mathrm{N}$-mehtyltransferase. Proceedings of the National Academay of Sciences, USA 98: $10001-10005$.

41. Moller I.M. (2001). Plant mitochondria and oxidative stresses: Electron transport, NADPH turnover, and metabolism of reactive oxygen species. Annual Review of Plant Physiology and Plant Molecular Biology 52: $561-591$.

42. Munns R. (2002). Comparative physiology of salt and water stress. Plant, Cell and Environment 25 (2): $239-250$.

43. Munns R. (2005). Genes and salt tolerance: bringing them together. New Phytologist 167: 645 - 663.

44. Munns R. \& Tester M. (2008). Mechanisms of salinity tolerance. Annual Review of Plant Biology 59: $651-681$.

45. Ndimba B.K., Chivasa S., Simon W.J. \& Slabas A.R. (2005). Identification of Arabidopsis salt and osmotic stress responsive proteins using two-dimensional difference gel electrophoresis and mass spectrometry. Proteomics 5: $4185-4196$.

46. Newton R.P. \& Smith C.J. (2004). Cyclic neucleotides. Phytochemistry 65 (17): $2423-2437$.

47. Ouyang S-Q., Liu Y-F., Liu P., Lei G., He S-J., Ma B., Zhang W-K., Zhang J-S. \& Chen S-Y. (2010). Receptorlike kinase OsSIK1 improves drought and salt stress tolerance in rice (Oryza sativa) plants. The Plant Journal $62(2): 316-329$.

48. Pastor M.M., Proft M. \& Pascual-Ahuir A. (2009). Mitochondrial function is an inducible determinant of osmotic stress adaptation in yeast. The Journal of Biological Chemistry 284: 30307 - 30317.

49. Rabello A.R., Guimarães C.M., Rangel P.H.N., da Silva F.R., Seixas D., de Souza E., Brasileiro A.C.M., Spehar C.R., Ferreira, M.E. \& Mehta A. (2008). Identification of drought-responsive genes in roots of upland rice (Oryza sativa L.). BMC Genomics 9: 485.

50. Rajendran K., Tester M. \& Roy S.J. (2009). Quantifying the three main components of salinity tolerance in cereals. Plant, Cell and Environment 32: 237 - 249.

51. Rapley R. (Ed) (2000). The Nucleic Acid Protocols Handbook. Humana Press Inc. USA.

52. Sahi C., Singh A., Kumar K., Blumwald E. \& Grover A. (2006a). Beyond osmolytes and transporters: novel plant salt-stress tolerance-related genes from transcriptional profiling data. Physiologia Plantarum 127 (1): 1 - 9.

53. Sahi C., Singh A., Kumar K., Blumwald E. \& Grover A. (2006b). Salt stress response in rice: genetics, molecular biology, and comparative genomics. Functional Integrative Genomics 6 (4): 263 - 284.

54. Sambrook J., Fritsch E.F., \& Maniatis T. (1989). Molecular Cloning: A Laboratory Manual, Vols. 1 and 3. Cold Spring Harbor Laboratory Press, Cold Spring Harbor, New York, USA. 
55. Schubert S., Neubert A., Schierholt A., Sümer A. \& Zörb C. (2009). Development of salt-resistant maize hybrids: the combination of physiological strategies using conventional breeding methods. Plant Science 177: 196 - 202.

56. Suzuki Y., Makino A. \& Mae T. (2001). An efficient method for extraction of RNA from rice leaves at different ages using benzyl chloride. Journal of Experimental Botany 52: 1575 - 1579 .

57. Szabolcs I. (1989). Salt-Affected Soils. CRC Press, Boca Raton, Florida, USA.

58. Thompson J.E., Hopkins M.T., Taylor C. \& Wang T-W. (2004). Regulation of senescence by eukaryotic translation initiation factor 5A: implications for plant growth and development. Trends in Plant Science 9: 174 - 179.

59. Vierstra R.D. \& Callis J. (1999). Polypeptide tags, ubiquitous modifiers for plant protein regulation. Plant Molecular Biology 41 (4): 435 - 442.

60. Wang X., Dong J., Liu Y. \& Gao H. (2010). A novel dehydration-responsive element-binding protein from Caragana korshinskii is involved in the response to multiple abiotic stresses and enhances stress tolerance in transgenic tobacco. Plant Molecular Biology Reporter 28 (4): $664-675$.

61. Wang Q., Guan Y., Wu Y., Chen H., Chan F. \& Chu C. (2008). Overexpression of a rice OsDREB1F gene increases salt, drought, and low temperature tolerance in both Arabidopsis and rice. Plant Molecular Biology 67 (6): $589-602$.

62. Wilen R.W., Hays D.B., Mandel R.M., Abrams S.R. \& Moloney M.M. (1993). Competitive inhibition of abscisic acid-regulated gene expression by stereoisomeric acetylenic analogs of abscisic acid. Plant Physiology 101 (2): $469-476$.

63. Xiong L., Woo Lee M., Qi M. \& Yang Y. (2001). Identification of defense-related rice genes by suppression subtractive hybridization and differential screening. Molecular Plant-Microbial Interactions 14 (5): $685-692$.

64. Xu D.Q., Huang J., Guo S.Q., Yang X., Bao Y.M., Tang H.J. \& Zhang H.S. (2008). Overexpression of a TFIIIA-type zinc finger protein gene ZFP252 enhances drought and salt tolerance in rice (Oryza sativa L.). FEBS Letters 582: $1037-1043$.

65. Yadav D.K., Islam S.M.S. \& Tuteja N. (2012). Rice heterodimeric G-protein Gamma subunits (RGG1 and RGG2) are differentially regulated under abiotic stress. Plant Signalling and Behaviour 7:1-8.

66. Yan J., Wang J. \& Zhang H. (2002). An ankyrin repeatcontaining protein plays a role in both disease resistance and antioxidation metabolism. The Plant Journal 29 (2): $193-202$.

67. Yoshida S., Forno A.D., Cock J.H. \& Gomez K.A. (1972) Laboratory Manual for Physiological Studies of Rice, pp.54, International Rice Research Institute, Los Banos, Philippines.

68. Zapata P.J., Serrano M., Pretel M.T., Amorós A. \& Botella M.A. (2003). Changes in ethylene evolution and polyamine profiles of seedlings of nine cultivars of Lactuca sativa L. in response to salt stress during germination. Plant Science 164: $557-563$.

69. Zapata P.J., Serrano M., Pretel M.T., Amorós A. \& Botella M.A. (2004). Polyamines and ethylene changes during germination of different plant species under salinity. Plant Science 167 (4): 781 - 788.

70. Zapata P.J., Serrano M., Pretel M.T., \& Botella M.A. (2008). Changes in free polyamine concentration induced by salt stress in seedlings of different species. Plant Growth Regulation 56: 167-177.

71. Zhang J.S., Xie C., Li Z.Y. \& Chen S.Y. (1999). Expression of the plasma membrane $\mathrm{H}^{+}$-ATPase gene in response to salt stress in a rice salt-tolerant mutant and its original variety. Theoretical and Applied Genetics 99 (6): $1006-1011$.

72. Zhou J., Wang X., Jiao Y., Qin Y., Liu X., He K., Chen C., Ma L., Wang J., Xiong L., Zhang O., Fan L. \& Deng X.W. (2007). Global genome expression analysis of rice in response to drought and high-salinity stresses in shoot, flag leaf, and panicle. Plant Molecular Biology 63: $591-608$. 